\title{
PERFORMANCE OF BHOTE TYPE GARLIC GENOTYPES UNDER KARNALI REGION OF NEPAL
}

Raj Kumar Giri ${ }^{1}$, Basant Chalise ${ }^{1,}$ Pragati Babu Paneru. Giri Dhari Subedi², Bishwash Poudel ${ }^{3}$, Homan Regmi ${ }^{4}$ Lokendra Rana $^{5}$, Dinesh Khadka ${ }^{6}$, D. B. Kathayat 7 , Chandra Budha ${ }^{7}$

\begin{abstract}
Advance Yield Trial on different Bhote type garlic genotypes collected from different districts of Nepal was carried out at Horticultural Research Station, Rajikot, Jumla for two consecutive years 2013/14 and 2014/15 to evaluate garlic genotypes suitable for the Karnali region of Nepal. Minimal work has been done in past on garlic, almost all of which centered at terai and mid hills that's why this study was carried out to select suitable bhote type garlic genotypes for high hill. Eleven different garlic genotypes were tested on Randomized Complete Block Design (RCBD) with three replication. Tested genotypes differed significantly for vegetative as well as yield parameters. During 2013, the highest bulb yield (47.41 t/ha) was recorded from ARM 01 followed by Mugu Local (47.01 t/ha), ARM 04 (46.98 t/ha), Kathmandu Local (45.41 t/ha), Chinese (37.91 t/ha) and the lowest from ARM 08 (20.1 t/ha). Similarly, during 2014/15, the highest bulb yield was observed from ARM 01 (50.32 t/ha) followed by Mugu Local (49.91 t/ha), Kathmandu Local (41.62 t/ha), Chinese (29.60 t/ha) and the lowest from ARM $05(12.51 \mathrm{t} / \mathrm{ha})$. Based on the average result of both years, ARM 01, Mugu Local, Kathmandu Local, ARM 04 and Chinese showed the better productivity ranged from $29.6 \mathrm{t} / \mathrm{ha}$ to $50.32 \mathrm{t}$ / ha which are the promising garlic genotypes for the Karnali region of Nepal.
\end{abstract}

Key words: Advance Yield Trial, Bhote type garlic, Parameters, Yield

\section{INTRODUCTION}

Garlic is an indispensable commodity of our kitchen. Its demand and consumption is increasing day by day however the production is almost stagnant far behind the domestic demand. Nepal is a net spices importing country, garlic being a major component, a huge amount of which is imported every year from neighboring countries. This account for a large sum of money outflow from our economy.

Though garlic cultivation started years back, lack of quality genotypes and appropriate package of practices (POP), has led to it being not very popular for commercial cultivation in Nepal. None of the garlic genotypes has been recommended, registered or released from NARC for cultivation in Nepal. There is subsistence cultivation of few land races and few other exotic germplasm introduced from adjoining country at different dates. Very few studies have been carried out in garlic. None of the variety is characterized and standard farming technology is yet to be developed.

Physio-morphological variation, crop duration and yield potentiality in Nepalese garlic germplasms for both qualitative and quantitative characters were studied by KC et.al, 2007. Eight different natural groups of more similar characteristics were identified on the basis of cluster analysis. Among 179 accessions, 21 including six Bhote Lasun adapted to summer cultivation in high hills of Nepal were unable to form bulbs under Chitwan (inner terai) condition. All Bhote Lasun, bore flowers in an umbel.

\footnotetext{
$1 \quad$ Horticultural Research Station, Rajikot, Jumla, rk1_giri@yahoo.com

$2 \quad$ Horticultural Research Division, Khumaltar, Lalitpur

3 Outreach Research Division, Khumaltar, Lalitpur

$4 \quad$ Biotechnology Division, Khumaltar, Lalitpur

$5 \quad$ High Value Agriculture Project, Jumla

6 Soil Science Division, Khumaltar, Lalitpur

7 District Agriculture Development Office, Jumla
} 
Similarly, Subedi and Bhandari, 2004 found 3rd week of September to 1st week of November was the most appropriate time of planting of garlic for foot hills and river basin areas of mid-western development region of Nepal

In Jumla, cultivated area under garlic is 5 ha and the production is $10 \mathrm{mt}$. Similarly, in the Karnali region, garlic has been cultivated under an area of 142 hectare with a total production of 420.6 Metric ton (MOAD, 2015). This accounts for only $1.99 \%$ of area and $0.94 \%$ of production of national area and production (7119 ha. and 44723 MT).

However, the productivity of garlic in the Karnali region is $2.96 \mathrm{Mt} /$ ha whereas the national productivity is 6.28 MT/ha which is far below than the national average (ABPSD, 2014/15). Similarly, total area cultivated in Jumla is 5 ha and production is 10 MT under garlic (DADO Jumla, 2015). This indicates the possibility of both vertical and horizontal expansion of garlic cultivation in this region by identifying the suitable genotypes and package of practices.

The demand of spices is at peak in October due to festive season and there is short supply of garlic. However, the agro-climatic condition in high hill allows production and supply to low lying areas during this peak period which fetches very high price. Moreover, being a non-perishable commodity, it can be easily stored under ordinary conditions incurring minimal postharvest losses.

Minimal work has been done in past on garlic, almost all of which centered at terai and mid hills. In spite of great production potential of high hills, garlic imported from Tibet to Kathmandu reaches the Karnali region via airways and vehicle incurring very high cost. This is a great misfortune of this region.

Several land races and few exotic germplasm are under cultivation and great deal of variability exists between them. A careful selection of locally adapted genotype and better crop husbandry can bring about improvements in qualitative and quantitative traits.

In the context of no any recommended, registered or released variety of garlic, an elaborate study of the same crop is must for germplasm selection, improvement and release as a new variety along with appropriate package of practices for commercialization of garlic. This may contribute to mass production leading to import substitution and export promotion of the same commodity.

\section{MATERIALS AND METHODS}

Eleven different germplasm of garlic collected from different districts of Nepal were tested under Advanced Yield Trial during 2013/2014 and 2014/2015 after conduction of observation nursery of 15 different garlic germplasm collected from different districts. The advanced yield trial was conducted at HRS, Rajikot, and Jumla. Eleven different germplasms: ARM 01, ARM 02, ARM 03, ARM 04, ARM 05, ARM 07, ARM 08, ARM 09, Mugu Local, Kathmandu Local (Ktm local) and Chinese, selected from observation nursery of garlic were tested. The plot size was assigned $0.75 \mathrm{~m} 2(1 \mathrm{~m} \mathrm{x}$ $0.75 \mathrm{~m}$ ). The plots were fertilized with $20 \mathrm{t}$ compost/ha. Selected cloves were planted with $15 \mathrm{~cm} \mathrm{x}$ $10 \mathrm{~cm}$ spacing. Randomized Complete Block Design (RCBD) with three replications was used. Planting and harvesting was done on the first week of Aswin and 3rd week of Asadh respectively. The necessary data for growth, yield and yield parameters were recorded and analysed with MSTATC.

\section{RESULT AND DISCUSSION}

During 2013/14, plant height, number of leaf per plant, width of leaf were found statistically non significant among the tested garlic genotypes. The tallest plants $(79.93 \mathrm{~cm})$ were measured from genotype Mugu Local followed by Kathmandu Local $(76.4 \mathrm{~cm})$ whereas the shortest $(48.27 \mathrm{~cm})$ plants were measured from ARM 04. 
Number of leaf per plant was counted maximum from Kathmandu Local (9.67) followed by ARM 01 (8.67) and ARM 07 (8.67) whereas the minimum number of leaves per plant were counted from ARM 04. Garlic genotype Chinese produced the longest leaves $(46.67 \mathrm{~cm})$ followed by Mugu Local $(42.44$ $\mathrm{cm})$ and ARM $01(42.33 \mathrm{~cm})$ and ARM 04 produced the shortest leaves $(23.78 \mathrm{~cm})$.

Width of leaf was maximum $(2.05 \mathrm{~cm})$ in genotype ARM 01 followed by Chinese $(2.01 \mathrm{~cm})$ and the narrowest leaves were recorded from ARM 03. Number of bulbs per ha was counted maximum from genotype ARM 07 (666667) followed by ARM 09, Mugu local, Kathmandu local (657778) whereas lowest (382222.3) from ARM 04.Diameter of bulb was maximum in genotype ARM $01(59.33 \mathrm{~mm})$ followed by Chinese and the lowest $(38.67 \mathrm{~mm})$ from ARM 04. Height of bulb was maximum (51.67 $\mathrm{mm}$ ) from genotype Mugu local and minimum from $27.89 \mathrm{~mm}$ ).

Number of cloves per bulb were counted maximum from Mugu local (23.67) followed by ARM 07 (14) and the least from ARM 04 (6.33). Yield of bulb was recorded the highest from genotype ARM 01 (47.41 t/ha) followed by Mugu local (47.01 t/ha) and the lowest ( $20.1 \mathrm{t} / \mathrm{ha})$ from ARM 08.

During 2014/15, all most all the vegetative and yield parameters were found statistically significant except number of cloves per bulb. The tallest plants $(74.18 \mathrm{~cm})$ were measured from genotype Mugu Local followed by genotypes Kathmandu Local $(72.57 \mathrm{~cm})$, ARM $04(66.22 \mathrm{~cm})$ and the shortest $(49.35 \mathrm{~cm})$ plants were measured from genotype Chinese. Number of leaves per plant was counted maximum (9.23) from genotype Kathmandu Local followed by Mugu Local (8.93), Chinese (8.55), ARM 07 whereas the least number (7.4) from genotype ARM 08. The longest leaves $(42.42 \mathrm{~cm})$ were measured from genotype Chinese followed by genotype ARM $01(39.67 \mathrm{~cm})$, Kathmandu Local $(38.67$ $\mathrm{cm})$, Mugu Local $(38.67 \mathrm{~cm})$ whereas the lowest $(24.50 \mathrm{~cm})$ from ARM 02. Width of the leaves were found maximum from genotype ARM $04(2.11 \mathrm{~cm})$ followed by genotype ARM $01(2.01 \mathrm{~cm})$, Chinese $(1.88 \mathrm{~cm})$ and the narrowest leaves $(0.88 \mathrm{~cm})$ were found from genotype ARM 03. Number of bulbs were counted maximum (666666.69) from genotype Mugu Local followed by ARM 02 (650000), ARM 01 (633333.31) and the lowest number of leaves (513333) were counted from genotype ARM 05.

Diameter of bulb was measured maximum $(63.61 \mathrm{~mm})$ from genotype ARM 01 followed by Kathmandu Local $(61.78 \mathrm{~mm})$, ARM $04(55.23 \mathrm{~mm})$ and the lowest $(40.16 \mathrm{~mm})$ from genotype ARM 08. Height of the bulb was measured maximum $(41.81 \mathrm{~mm})$ from genotype Kathmandu Local followed by Mugu Local $(41.35 \mathrm{~mm})$, ARM $03(41.25 \mathrm{~mm})$ and the minimum $(32.69 \mathrm{~mm})$ from genotype Chinese. Though the number of cloves per bulb was statistically non-significant, genotype Mugu Local produced the maximum cloves (19.3) per bulb and the minimum (7.4) from genotype ARM 01. Bulb yield per ha was maximum (50.32 ton) from genotype ARM 01 followed by genotype Mugu Local (49.91 ton), Kathmandu Local (41.62 ton) whereas the genotype ARM 05 produced the lowest (12.51 ton) bulb.

Colour of bulb was found white in ARM 01, ARM 02, ARM 04, ARM 05 and ARM 08. Light onion colour was observed in ARM 03, ARM 07, ARM 09. Similarly, onion colour was recorded in Mugu local and Kathmandu local.

ARM 01 was found slightly bitter and more pungent, ARM 09 and Kathmandu local were found more pungent. Similarly, ARM 04 (slightly bitter), ARM 07 and ARM 08 were medium pungent whereas ARM 02, ARM 03, ARM 05, Mugu local, Chinese were less pungent.

Significant differences among the vegetative as well as yield parameters show the wider genetic diversity as well as variability among the tested garlic genotypes. Significantly more bulb yield from ARM 01 (47.41 t/ha and 50.32 t/ha) during 2013/14 and 2014/15 among the tested garlic genotypes was obtained. In addition to these, Mugu Local (47.01 t/ha and $49.91 \mathrm{t} / \mathrm{ha}$ ), Kathmandu Local (45.41 t/ha and 41.62 t/ha), ARM 04 (46.98 t/ha and 32.05 t/ha) and Chinese (37.61 t/ha and 29.60 t/ha) 
were also high yielders among the tested garlic genotypes. This result clarifies their genetic potentiality to perform better under high hill conditions and uplift the lower productivity of the garlic. Though the yield potentiality of ARM 01 and ARM 04 was high, these genotypes may be suitable for industrial purpose due to slight bitterness and few number of large size cloves. Mugu local, Kathmandu local and Chinese are better for kitchen/spice purpose. In addition to this, Chinese matures earlier than the high yielding genotypes listed herewith.

Table 1: Advance Yield Trial of garlic during 2013/14 at HRS, Rajikot, Jumla

\begin{tabular}{|c|c|c|c|c|c|c|c|c|c|c|}
\hline SN & Treatments & $\begin{array}{l}\text { Plant } \\
\text { ht }(\mathrm{cm})\end{array}$ & $\begin{array}{c}\text { No. of } \\
\text { leaf }\end{array}$ & $\begin{array}{l}\text { Length of } \\
\text { leaf }(\mathrm{cm})\end{array}$ & $\begin{array}{l}\text { Width of } \\
\text { leaf }(\mathrm{cm})\end{array}$ & $\begin{array}{c}\text { No. of } \\
\text { bulbs/ha }\end{array}$ & $\begin{array}{c}\text { Diameter } \\
\text { of bulb } \\
\text { (mm) }\end{array}$ & $\begin{array}{c}\text { Height of } \\
\text { bulb } \\
\text { (mm) }\end{array}$ & $\begin{array}{c}\text { No. of } \\
\text { cloves/bulb }\end{array}$ & $\begin{array}{c}\text { Bulb } \\
\text { yield } \\
\text { (mt/ha) }\end{array}$ \\
\hline 1 & ARM-01 & 58.87 & 8.67 & $42.33 \mathrm{ab}$ & 2.05 & 404444.3 & 59.33 & $43.33 \mathrm{a}$ & $6.67 c$ & $47.41 \mathrm{a}$ \\
\hline 2 & ARM-02 & 61.27 & 7.93 & $27.89 \mathrm{bc}$ & 1.27 & 533333.3 & 46 & $51.11 \mathrm{a}$ & $10 \mathrm{bc}$ & $23.36 \mathrm{bc}$ \\
\hline 3 & ARM-03 & 61.53 & 8.4 & $32.78 \mathrm{abc}$ & 1.11 & 608889 & 43.94 & $46.22 \mathrm{a}$ & 8 bc & $25.61 \mathrm{abc}$ \\
\hline 4 & ARM-04 & 48.27 & 4.8 & $23.78 \mathrm{c}$ & 1.54 & 382222.3 & 38.67 & $27.89 \mathrm{~b}$ & $6.33 c$ & $46.98 \mathrm{a}$ \\
\hline 5 & ARM-05 & 61.27 & 8.33 & $30.34 \mathrm{bc}$ & 1.5 & 617778 & 43.61 & $42.11 \mathrm{a}$ & $10.33 \mathrm{bc}$ & $25.58 \mathrm{abc}$ \\
\hline 6 & ARM-07 & 67.93 & 8.67 & $32.33 \mathrm{abc}$ & 1.38 & 666667 & 45.78 & $47.11 \mathrm{a}$ & $14 \mathrm{~b}$ & $36.71 \mathrm{abc}$ \\
\hline 7 & ARM-08 & 56.87 & 7.53 & 28.44 bc & 1.5 & 635555.7 & 39.22 & $40.34 \mathrm{ab}$ & $9.33 \mathrm{bc}$ & $20.1 \mathrm{c}$ \\
\hline 8 & ARM-09 & 70.27 & 8.27 & $33.56 \mathrm{abc}$ & 1.46 & 657778 & 48.94 & $47.89 a$ & $13 \mathrm{~b}$ & $37.08 \mathrm{abc}$ \\
\hline 9 & Mugu & 79.93 & 8.73 & $42.44 \mathrm{ab}$ & 1.37 & 657778 & 50.5 & $51.67 \mathrm{a}$ & $23.67 \mathrm{a}$ & $47.01 \mathrm{a}$ \\
\hline 10 & Ktm Local & 76.4 & 9.67 & $41 a b$ & 1.8 & 657777.7 & 51.72 & $50.33 a$ & $10.67 \mathrm{bc}$ & $45.41 \mathrm{ab}$ \\
\hline 11 & Chinese & 54.33 & 8.13 & $46.67 \mathrm{a}$ & 2.01 & 644444.3 & 56.17 & $48.67 \mathrm{a}$ & $11 \mathrm{bc}$ & $37.91 \mathrm{abc}$ \\
\hline & $P$ & ns & ns & * & ns & ns & ns & * & $* * *$ & * \\
\hline & CV (\%) & 21.36 & 18.23 & 22.07 & 35.32 & 24.53 & 22.85 & 16.94 & 28.93 & 33.3 \\
\hline & LSD & & & 13.04 & & & & 13.03 & 5.509 & 19.74 \\
\hline
\end{tabular}

Table 2: Advance Yield Trial of garlic during 2014/15 at HRS, Rajikot, Jumla

\begin{tabular}{|l|l|c|c|c|c|c|c|c|c|c|}
\hline SN & Treatments & $\begin{array}{c}\text { Plant ht } \\
(\mathbf{c m})\end{array}$ & $\begin{array}{c}\text { No. of } \\
\text { leaf }\end{array}$ & $\begin{array}{c}\text { Length } \\
\text { of leaf } \\
(\mathbf{c m})\end{array}$ & $\begin{array}{c}\text { Width of } \\
\text { leaf }(\mathbf{c m})\end{array}$ & $\begin{array}{c}\text { No. of } \\
\text { bulbs/ha }\end{array}$ & $\begin{array}{c}\text { Diameter } \\
\text { of bulb } \\
(\mathbf{m m})\end{array}$ & $\begin{array}{c}\text { Height of } \\
\text { bulb } \\
(\mathbf{m m})\end{array}$ & $\begin{array}{c}\text { No. of } \\
\text { cloves/ } \\
\text { bulb }\end{array}$ & $\begin{array}{c}\text { Bulb } \\
\text { yield } \\
(\mathbf{m t} / \mathrm{ha})\end{array}$ \\
\hline 1 & ARM-01 & $54.70 \mathrm{de}$ & $8.48 \mathrm{abcd}$ & $39.67 \mathrm{a}$ & $2.01 \mathrm{a}$ & $599999.98 \mathrm{e}$ & $63.61 \mathrm{a}$ & $37.93 \mathrm{abc}$ & 7.4 & $50.32 \mathrm{a}$ \\
\hline 2 & ARM-02 & $56.42 \mathrm{de}$ & $7.53 \mathrm{~cd}$ & $24.50 \mathrm{c}$ & $1.02 \mathrm{~cd}$ & $650000 \mathrm{~b}$ & $51.94 \mathrm{bc}$ & $40.97 \mathrm{a}$ & 12.8 & $30.12 \mathrm{abc}$ \\
\hline 3 & ARM-03 & $57.38 \mathrm{~d}$ & $7.93 \mathrm{bcd}$ & $29.75 \mathrm{bc}$ & $0.88 \mathrm{~d}$ & $633333.31 \mathrm{c}$ & $51.46 \mathrm{c}$ & $41.25 \mathrm{a}$ & 8.8 & $25.21 \mathrm{bc}$ \\
\hline 4 & ARM-04 & $66.22 \mathrm{bc}$ & $7.88 \mathrm{bcd}$ & $31.83 \mathrm{~b}$ & $2.11 \mathrm{a}$ & $550000 \mathrm{~g}$ & $55.23 \mathrm{abc}$ & $33.89 \mathrm{c}$ & 7.8 & $32.05 \mathrm{abc}$ \\
\hline
\end{tabular}




\begin{tabular}{|l|l|c|c|c|c|c|c|c|c|c|}
\hline 5 & ARM-05 & $55.63 \mathrm{de}$ & $8.25 \mathrm{abcd}$ & $28.42 \mathrm{bc}$ & $1.29 \mathrm{~cd}$ & $513333.34 \mathrm{i}$ & $41.76 \mathrm{~d}$ & $34.56 \mathrm{bc}$ & 7.8 & $12.51 \mathrm{c}$ \\
\hline 6 & ARM-07 & $64.30 \mathrm{c}$ & $8.40 \mathrm{abcd}$ & $27.75 \mathrm{bc}$ & $1.19 \mathrm{~cd}$ & $523333.34 \mathrm{~h}$ & $53.63 \mathrm{bc}$ & $37.87 \mathrm{abc}$ & 10.8 & $21.21 \mathrm{bc}$ \\
\hline 7 & ARM-08 & $52.22 \mathrm{de}$ & $7.40 \mathrm{~d}$ & $24.75 \mathrm{c}$ & $1.37 \mathrm{bcd}$ & $566666.66 \mathrm{f}$ & $40.16 \mathrm{~d}$ & $34.10 \mathrm{c}$ & 10.1 & $16.16 \mathrm{c}$ \\
\hline 8 & ARM-09 & $64.45 \mathrm{c}$ & $7.98 \mathrm{bcd}$ & $29.84 \mathrm{bc}$ & $1.20 \mathrm{~cd}$ & $593333.34 \mathrm{e}$ & $53.85 \mathrm{bc}$ & $40.34 \mathrm{ab}$ & 12.6 & $30.49 \mathrm{abc}$ \\
\hline 9 & Mugu & $74.18 \mathrm{a}$ & $8.93 \mathrm{ab}$ & $38.67 \mathrm{a}$ & $1.15 \mathrm{~cd}$ & $666666.69 \mathrm{a}$ & $57.22 \mathrm{abc}$ & $41.35 \mathrm{a}$ & 19.3 & $49.91 \mathrm{a}$ \\
\hline 10 & Ktm Local & $72.57 \mathrm{ab}$ & $9.23 \mathrm{a}$ & $38.67 \mathrm{a}$ & $1.55 \mathrm{abc}$ & $623333.34 \mathrm{~d}$ & $61.78 \mathrm{ab}$ & $41.81 \mathrm{a}$ & 10.9 & $41.62 \mathrm{ab}$ \\
\hline 11 & Chinese & $49.35 \mathrm{e}$ & $8.55 \mathrm{abc}$ & $42.42 \mathrm{a}$ & $1.88 \mathrm{ab}$ & $620000 \mathrm{~d}$ & $53.56 \mathrm{bc}$ & $32.69 \mathrm{c}$ & 9.5 & $29.60 \mathrm{bc}$ \\
\hline & P & $* * *$ & $*$ & $* * *$ & $* * *$ & $*$ & $* * *$ & $* *$ & $\mathrm{~ns}$ & $*$ \\
\hline & CV $(\%)$ & 7.61 & 7.99 & 10.76 & 25.88 & 10.57 & 11.46 & 10.13 & 31.38 & 40.34 \\
\hline & LSD & 6.668 & 0.950 & 5.033 & 0.530 & 9077 & 8.788 & 5.543 & & 17.96 \\
\hline
\end{tabular}

\section{CONCLUSION AND RECOMMENDATION}

Based on the results of observation nursery, only 11 different garlic genotypes: ARM 01, ARM 02, ARM 03, ARM 04, ARM 05, ARM 07, ARM 08, ARM 09, Mugu Local, Kathmandu Local and Chinese were selected and tested under Advance Yield Trial during 2013/14 and 2014/15. During both of the years, ARM 01, Mugu Local, Kathmandu Local, ARM 04 and Chinese perform better with respect to productivity ranging from $29.6 \mathrm{t} / \mathrm{ha}$ to 50.32 which is 5 to 8 times higher than the national productivity $(6.28 \mathrm{t} / \mathrm{ha})$. Similarly, these genotypes perform better with respect to vegetative parameters too. Plant height of these genotypes ranged from $49 \mathrm{~cm}$ to $79 \mathrm{~cm}$, no. of leaves per plant ranged between 8 and 9, length of leaf ranged from 38 to 46 and width of leaves ranged between 1.15 and 2.05. All these vegetative parameters supports in more photosenthesis which ultimately results in more yield. As per the result of both of the years, ARM 01, Mugu Local, Kathmandu Local and Chinese are the promising garlic genotypes for Jumla and similar locations of Karnali Region of Nepal.

\section{REFERENCES}

ABPSD. 2014/15. Statistical information on Nepalese agriculture. Agri-business promotion and statistics Division, MOAD, Kathmandu, Nepal.

DADO, Jumla, 2015. Annual Progress Report, 2010.

G.D Subedi and K.B Bhandari, 2004. Effect of planting date on garlic (Allium sativum L.) bulb yield in the river basin areas of western Nepal. Proceedings of the Fourth National Horticulture Workshop, 2004, Nepal Agricultural Research Council.

MOAD, 2015. Statistical Information on Nepalese Agriculture. MOAC, Agribusiness Promotion and Statistics Division. Kathmandu, Nepal.

R. B. KC, M. D. Sharma, D. M. Gautam and D. R. Panthee, 2007. Characterization and evaluation of indigenous garlic (Alium sativum L.) germplasms of Nepal. IAAS Research Advances Vol. 1, 2007. Institute of Agriculture and Animal Sciences, Rampur, Chitwan, Nepal. 